\title{
Peran Agama dalam Kesehatan Mental \\ (Kajian Psikologis atas Kisah Maryam Binti Imran dalam QS Maryam: 18-22)
}

\author{
Muhammad Shodiq Masrur \\ Universitas Islam Negeri Sunan Kalijaga Yogyakarta \\ E-mail: masrurshodiq@gmail.com \\ Azka Salsabila \\ Universitas Islam Negeri Sunan Kalijaga Yogyakarta \\ E-mail: billazka@gmail.com
}

\begin{abstract}
Abstrak: al-Qur'an adalah firman dan kasih sayang Allah kepada hamba-Nya. Manusia hidup tanpa al-Qur'an akan mengalami keresahan dan kehilangan tujuan hidup. Sebab al-Qur'an merupakan pedoman dalam segala aspek dan mampu memberikan solusi atas segala permasalahan hidup manusia, baik dari segi fisik atau mental. Bukti tersebut sudah terbukti kebenaranya di dalam Surat Maryam, sebagaimana Maryam binti Imran ketika mengalami persoalan hidup seacara mental, mampu terselesaikan hanya dengan berpedoman pada firman Allah. Penulisan ini bertujuan untuk menggambarkan peran agama dalam menyelesaikan permasalahan hidup dan menyembuhkan psikis yang dihadapi Maryam Binti Imran. Jenis penelitian ini kepustakaan, sumber data yang diambil buku-buku, jurnal, ayat al-Qur'an yang relevan, pengumpulan data dengan cara (library research)dan metode analisis data mengunakan analisis deskriptif dan interpretatif. Hasil dari penelitian ini ialah dengan memperkuat iman dan tauhid dengan beribadah sesuia dengan tuntunan yang Allah dan Rasul ajarkan akan mengantarkan manusia pada kebahagiaan dan kesehatan mental serta mampu mengoptimalkan potensi pada diri manusia.
\end{abstract}

Kata Kunci: Peran Agama, Kesehatan Mental, Maryam

\begin{abstract}
The Qur'an is the word and love of Allah to His servants. Humans living without the Qur'an will experience anxiety and loss of purpose in life. Because the Qur'an is a guide in all aspects and is able to provide solutions to all problems of human life, both in terms of physical or mental. The evidence has been proven true in the Letter of Mary, as Maryam bint Imran when experiencing mental life problems, can be resolved only by referring to the word of God. The purpose of this writing is to describe the role of religion in solving life's problems and healing psychics faced by Maryam Bint Imran. This type of research is literature, data sources taken by books, journals, relevant Qur'anic verses, data collection by means of (library research) and data analysis methods use descriptive and interpretive analysis. The results of this research are to strengthen faith and monotheism by worshiping in accordance with the guidance that Allah and the Apostle teach will lead people to happiness and mental health and be able to optimize the potential in humans.
\end{abstract}

Keywords: The Role of Religion, Mental Health, Maryam 


\section{Pendahuluan}

Kehidupan manusia di masa dulu, sekarang atau masa depan diharapkan mampu berpedoman kepada Alquran. Sebab Alquran adalah petunjuk, penjelas dan pembeda bagi manusia. Bahkan Alquran lebih dari itu, Alquran tidak hanya berfungsi sebagai petunjuk hidup, tetapi berfungsi juga untuk menghidupkan manusia baik secara fisik maupun psikis. Yang dimaksud menghidupkan ialah karena Alquran dari masa dulu, sekarang dan masa depan akan tetap eksis dalam kehidupan sehari-hari. Dengan kata lain, Alquran ada pada diri kita, sekitar kita dan dimanapun kita berada. Alquran menjadi teman hidup, inspirasi, sekaligus tempat konsultasi, mediasi dan solusi dalam menghadapi berbagai problema hidup yang dihadapi manusia ${ }^{1}$.Berdasarkan uraian tersebut, ternyata terbukti pada kisah Maryam binti Imron. Ketika itu dikisahkan bahwa Maryam binti Imran adalah perempuan yang mulia dan mengibahkan dirinya untuk beribadah kepada Allah. Dialah perempuan yang mendapatkan kehormatan ditiupkan ruh ke dalam rahimnya tanpa hubungan biologis dengan seorang suami. Kemulian yang sekaligus menjadi persoalan hidup bagi Maryam binti Imran. Dengan demikian, dari kisah Maryam binti Imran tersebut menimbulkan asumsi dan pertanyaan bagi peneliti bahwa bagaimana kondisi mental Maryam binti Imron ketika pertama kali mendapatkan kabar dari malaikat Jibril dirinya akan hamil tanpa hubungan biologis.

M. Quraish Shihab pakar tafsir menjelaskan di surat Maryam ayat 18-22 bahwa kesehatan mental pada psikis Maryam binti Imran mengalami terheran-heran, kecemasan, dan rasa ketakutan ketika malaikat Jibril memberikan kabar terkait akan ditiupkan ruh ke dalam rahimnya. ${ }^{2}$ Berpedoman kepada Dali Gulo pakar psikologi berpendapat bahwa keadaan Maryam binti Imran yang mengalami kecemasan dan ketakutan tersebut, pertanda psikisnya sedang mengalami neurosis. Yang dimaksud neurosis ialah kelainan mental ringan yang sering ditandai dengan keadaan cemas yang kronis, gangguan-gangguan pada indera dan motorik, hambatan emosi, kurang perhatian terhadap lingkungan dan kurang mengalami energi fisik ${ }^{3}$. Kondisi psikis tersebut dapat terjadi karena Maryam binti Imran adalah seorang manusia biasa yang memiliki dua potensi yaitu fisik dan psikis. Manusia dikatakan sakit mental, apabila keharmonisan jiwa dengan kesanggupan untuk menghadapi problema hidup tidak mampu tercitpta, pasti akan mengalami sakit mental. Sebaliknya, manusia dapat dikatakan memiliki kesehatan mental ketika kondisi batin yang senantiasa berada dalam posisi tenang, aman dan tentram.

Zakiah Drajat berpendapat bahwa ketenangan batin dapat ditemukan melalui penyesuian diri secara pasrah ${ }^{4}$.Yang dimaksud pasrah ialah menyerahkan semua persoalan hidup kepada Allah yang Maha Kuasa dan Maha Segalanya. Zakiah Dardjat juga berpendapat bahwa tanpa Allah psikis manusia tidak dapat merasakan ketenangan dan kebahagian dalam hidup5. Berdasarkan pendapat di atas, dapat dipahami bahwa kepercayaan kepada Allah dan agama merupakan penolong bagi manusia untuk memenuhi kekosongan batin atau psikis. Agama dimaknai sebagai unsur yang terpenting dalam kehidupan dan agama sangat

\footnotetext{
${ }^{1}$ Zainol Hasan, "Nilai-Nilai Pendidikan Islam Pada Kisah Nabi Ibrahim", Jurnal Nuansa, Vol. 14, No. 2 (JuliDesember, 2017), 14.

${ }^{2}$ M. Quraish Shihab, Tafsir Al-Misbah, Pesan, Kesan dan Keserasian al-Quran Volume (Jakarta: Lentera Hati 2002), 426-428.

${ }^{3}$ Zakiah Drajat,Peran Agama dan Kesehatan Mental, (Jakarta: Masagung, 1990), 56.

${ }^{4}$ Ibid., 12.

${ }^{5}$ Ibid., 11
} 
menentukan dalam pembangunan psikis, batin atau mental bagi manusia. Dalam konteks ini, Ramayulis berpendapat sebagai pakar psikologi agama bahwa agama memiliki empat fungsi dalam upaya menghilangkan problematika psikis yang dialami manusia; pertamaagama sebagai sarana untuk menjaga kesusilaan, keduaagama sebagai sarana mengatasi ketakutan, ketigaagama sebagai sarana untuk mengatasi frustasi, keempat agama sebagai sarana pemuas intelektual.Sementara pendapat lain, seorang pakar psikologi dari Amerika Serikat mengatakan bahwa terapi yang terbaik bagi keresahan hati adalah keimanan kepada Allah. Keimanan kepada Allah merupakan salah satu kekuatan yang harus dipenuhi untuk membimbing seseorang dalam menjalani hidup ini yang penuh dengan cobaan yang silih berganti tanpa henti.

Maryam binti Imran sudah membuktikan bahwa yang mampu menguatkan psikis manusia yang lemah adalah agama dan keimanan. Secara fakta ketika Maryam bintiImran, mendapatkan kabar dari malaikat jibril akan hamil tanpa hubungan biologis, dituduh zina sekaligus diusir dari lingkungan sosial masyarakat Bani Israil, hingga akhirnya dibimbing dan diturunkan sebuah pertolongan dari Allah untuk menyelesaikan persoaal hidup yang dihadapi Maryam binti Imran. Berdasarkan atas uraian tersebut dapat dipahami bahwa Allah menyembuhkan psikis dan menyelesaikan persoalan hidup yang dihadapi Maryam binti Imran dengan beberapa tahapan yang diabadikan di dalam Alquran. Pada intinya Maryam binti Imran adalah manusia biasa yang tergolong perempuan yang lemah psikis, tetapi memiliki keimanan yang kuat, bertaqwa dan sepanjang hidupnya berkhidmat kepada Allah, sehingga Maryam binnti Imran tetap tegar dan tabah dalam menghadapi cobaan hidup. Penulisan ini bertujuan untuk mengetahui :(1) bagaimana peran agama dalam kesehatan mental bagi manusia. (2) bagaimana Allah membimbing dan menyembuhkan psikis Maryam binti Imran. Metode penulisan menggunakan content analysis, semacam teknik yang dapat digunakan untuk mengkaji sumber data berupa Alquran, buku, teks, esay, dan artikel, dengan pendekatan deskriptif eksploratif.

Metode yang digunakan pada kajian ini menggunakan metode atau pendekatan kepustakaan (library research), Studi pustaka atau kepustakaan dapat diartikan menjadi serangkaian kegiatan yang berkenaan menggunakan metode pengumpulan data pustaka, membaca serta mencatat serta mengolah bahan penelitian ${ }^{6}$. Pada penelitian studi pustaka setidaknya ada empat karakteristik utama yang penulis perlu perhatikan diantaranya :

Pertama, bahwa penulis atau peneliti berhadapan langsung dengan teks (nash) atau data angka, bukan menggunakan pengetahuan eksklusif berasal lapangan. Kedua, data pustaka bersifat "siap pakai" adalah peniliti tidak terjun pribadi kelapangan sebab peneliti berhadapan eksklusif menggunakan sumber data yang ada pada perpustakaan. Ketiga, bahwa data pustaka umumnya merupakan asal sekunder, pada arti bahwa peneliti memperoleh bahan atau data berasal tangan kedua serta bukan data orisinil dari data pertama pada lapangan. Keempat, bahwa syarat data pustaka tidak dibatasi sang runga dan waktu ${ }^{7}$.Berdasarkan menggunakan hal tadi diatas, maka pengumpulan data pada penelitian dilakukan dengan mempelajari dan atau mengekplorasi beberapa Jurnal, kitab , serta dokumen-dokumen (baik yang berbentuk cetak juga elektro) serta sumber-sumber data dan atau info lainnya yang dianggap relevan dengan penelitian atau kajian.

\footnotetext{
${ }^{6}$ Mustika Zed, Metode Penelitian Kepustakaan (Jakarta: Yayasan Obor Indonesia, 2003), 3.

${ }^{7}$ Ibid., 4-5.
} 


\section{Peran Agama dan Relevansinya dalam Ruang Psikologis Manusia}

Syaiful Hamali mengutip pendapat Norman Vincent Peale mengatakan bahwa agama merupakan alat atau perantara yang dapat memberikan rasa keimanan dan rasa keyakinan kepada manusia untuk pasrah dan memohon pertolongan kepada Allah dari segala hal yang tidak menyenangkan dari problem-problem yang dihadapi. ${ }^{8}$ Najati mengutip pendapat Arnold Toynbee bahwa agama penting bagi kehidupan manusia, ketika itu diceritakan krisis yang dialami oleh orang Eropa pada masa modern ini disebabkan oleh karena kemiskinan spiritual yang jalan untuk menyembuhkan tiada lain hanya dengan kembali pada agama ${ }^{9}$.Berdasarkan cerita di atas, dapat dipahami bahwa manusia di masa modernisasi mulai mengabaikan unsurunsur spiritual dan mengagungkan sifat yang mengandung nilai-nilai materi dalam kehidupan, sehingga menciptakan krisis, seperti hubungan antara agama dengan kebudayaan semakin merenggang, oleh karena disebabkan nilai-nilai agama semakin memudar dalam bersikap dan beringkah laku. Fenomena tersebut berdampak pada nilai kebudayaan yang bersumber pada ajaran agama berubah menjadi nilai sosial yang bersifat sekuler. Dengan demikian, dari aspek itulah penyebab berbagai permasalahan kejiwaan manusia di dalam kehidupan.Berdasarkan urain teori di atas, dapat dipahami bahwa pada intinya agama merupakan kebutuhan pokok manusia karena hanya agama yang dapat memberikan solusi atas persoalan yang dihadapi manusia secara fisik atau terkait masalah psikis (sakit mental) di dalam kehidupan sehari-hari.

Agama dapat dimaknai sebagai alat untuk menyembuhkan jiwa melalui ajaran-ajaran agama. Sebab dari aspek ilmu kesehatan jiwa ada dua macam bentuk pengobatan yaitu pertama somoterapi. Yang dimaksud somoterapi ialah pengobatan secara fisik berupa obatobatan. Keduadengan cara pengobatan psikoterapi. Yang dimaksud psikoterapi ialah pengobatan yang tidak mengutamakan pada bagian badan yang sakit atau anggota fisik yang terganggu, tetapi lebih diutamakan di bagian psikis (mental emosional)dengan berpedoman pada kajian ilmu psikologi. ${ }^{10}$ Pengobatan secara psikoterapi menjadi metode psikologi sebagai solusi agama terhadap problematika psikis manusia. Apalagi manusia merupakan makhluk hidup yang memiliki kesatuan potensi jasmani dan rohani. Sementara hubungan rohani dan agama ada kaitanya dengan sikap keyakinan. Yang dimaksud keyakinan ialah perilaku yang bersifat pasrah diri manusia terhadap kekuasan Allah. Sifat pasrah merupakan cerminan dari sudut pandang secara positif pada diri manusa sehingga menciptakan perasaan positif seperti bahagia, merasa dicintai dan aman.

Langkah untuk menemukan makna kebahagian hidup bagi manusi secara sudut pandang kajian ilmu psikologi ada yang namanya logoterapi. Yang dimaksud logoterapi ialah semacam terapi dari kegiatan yang berpotensi memberikan peluang kepada manusia untuk menemukan makna hidup. Adapun kegiatan yang dimaksud dalam terapi logoterapi meliputi berkarya, cinta dan penderitaan. Tetapi kegiatan yang bersifat terapi tersebut sulit terlaksana maka ibadah dari ajaran agama merupakan salah satu cara yang paling mudah digunakan untuk membuka sudut pandangan manusia akan nilai-nilai potensial dan kebahagian hidup ${ }^{11}$. Berdasarkan urain tersebut, dapat dipahami bahwa apabila manusia menjauhkan diri dari sang

\footnotetext{
${ }^{8}$ Syaiful Hamali, “Terapi Agama Terhadap Promblematika Psikis Manusia,” Jurnal Al-AdyanVol. IX, No. 2, (Juli-Desember 2014).

${ }^{9}$ Najati, Al-Quran Dan Ilmu Jiwa (Bandung: Pustaka, 1985), 288.

${ }^{10}$ A Faruq Nasution. Thibburruhany Atau Faith-Heeling Psikology (Iman Dalam Kesehatan Jiwa Dan Badan) (Jakarta: Publik Komunikasi Ilmiah Ulum Eldine, 1976), 32.

${ }^{11}$ Bahri Ghazali. Kesehatan Mental II (Bandar Lampung: Harko Indo, 2008), 143-152.
} 
Maha pencipta, itu artinya manusia sedang mengosongkan diri dari nilai-nilai agama, hal sedemikian merupakan kerugian terbesar bagi manusia selaku makhluk berdimensi spiritual.

Sementara pendapat lain, menurut Mulyadi bahwa agama dalam kehidupan manusia berperan sebagai motivasi dalam mendorong untuk melakukan aktivitas yang bersifat positif, karena sikap yang dilakukan yang berpedoman keyakinan terhadap agama dinilai mempunyai unsur kesucian dan bersifat ketaatan ${ }^{12}$. Secara umum uraian tersebut dapat disaksikan dan dibuktikan dalam pengalaman kehidupan nyata bahwa Alquran sudah mengabadikannya di kisah Maryam binti Imran. Sebagaimana dikisahkan dalam Alquran, Maryam binti Imram adalah manusia yang berpedoman pada agama dan memiliki ketaatan dan keyakinan yang bersifat pasrah kepada Allah. Alquran menggambarkan bentuk kepasrahan yang dilakukan Maryam binti Imramterletak pada surat Maryam ayat 30. Ketika itu dikisahkan Bani Israil berprasangka buruk terhadap Maryam binti Imran dan tidak ada satupun yang percaya bahwa kehamilan yang dialami Maryam binti Imran merupakan bagian wujud kemuliaan dan ketetapan Allah. Bahkan Bani Israil tetap mengira Maryam binti Imran sudah melakukan berbuatan hina yang berupa zina. Berdasarkan pendapat M. Quraish Shihab pakar tafsir bahwa meskipun dihina, diasingkan dan dipandang rendah, Maryam binti Imran tetap menyerahkan segala persoalan tersebut kepada sang Maha pencipta. Alhasil psikis Maryam binti Imran tetap tegar dan tenang dalam menghadapi segala tuduhan Bani Israil.

Berpedoman pada pendapat William James pakar filosof dan ahli ilmu jiwa bahwa keimanan yang yang dimiliki Maryam binti Imran adalah terapi terbaik bagi keresahan yang melanda manusia, karena keimanan salah satu kekuatan yang harus terpenuhi dalam rangka menopang hidup manusia. Keimanan yang kuat akan melindungi manusia dari keresahan dan selalu tabah sekaligus tegar menghadapi segala cobaan atau penderitaan yang menimpa ${ }^{13}$.Selanjutnya berdasarkan atas petunjuk dan bimbingan yang diberikan Allah. Maryam binti Imran dikisahkan menunjuk kepada Isa lalu berkata "Tanyalah anak ini, dia akan menjelaskan kepada kalian duduk perkaranya"14. Tanpaditerima nalar, berkat keyakinan dan kepasrahan kepada agama. Maryam binti Imran mendapatkan pertolongan, dari sikap kepasrahan tersebut. Allah memberikan pertolongan untuk menyelesaikan problematika hidup yang dihadapi Maryam binti Imran dengan memberikan kuasa di luar nalar bahwa anak yang masih di gendongan dapat berkata "Sesungguhnyaaku hamba Allah. Dia telah memberiku al-kitab dan Dia telah menjadikan aku seorang nabi".'Dengan demikian, merujuk pada teori dan kisah di atas, dapat dipahami bahwa ada berbedaan besar antara manusia yang memiliki keyakinandengan manusia yang tidak memiliki keyakinan dan sering acuh-tak acuh kepada agama. Hal tersebut tergambarkan dari aspek psikologi bahwa rawud wajah manusia yang hidup dengan berpegang teguh terhadap keyakinan agama terlihat ketentraman pada batin, sikap tenang dan tidak memiliki sikap gelisah serta kecemasan dan ketakutan.Sebaliknya bagi manusia yang hidupnya terlepas dari peran agama, akan tergambarkan dengan psikis yang terganggu oleh kegoncangan dari persoalan hidup, sehingga menimbulkan kebingungan,ketakutan dan frustasi. Sedangkan apabila manusia memiliki sikap frustasi dan rasa ketakutan akan menimbulkan ketegangan batin, konflik batin dan gangguan emosional, yang menjadi penyebab timbulnya ketidaksehatan mental bagi manusia.

\footnotetext{
${ }^{12}$ Mulyadi, “Agama Dan Pengaruhnya Dalam Kehidupan.” Jurnal Tarbiyah Al-Awlad VI (2016). 556-564

${ }^{13}$ Rifqi Rosyad, "Pengaruh Agama Terhadap Kesehatan Mental," Jurnal Shifa Al-Qulub Vol. I, No. 2 (2016).

${ }^{14}$ M. Quraish Shihab,Tafsir Al-Misbah, 439.
} 


\section{Diskursus Kesehatan Mental dalam Kisah Maryam}

Mendiagnosa manusia apakah terganggu mentalnya atau tidak bukanlah persoalan yang mudah, karena disebabkan sulit untuk diukur, diperiksa ataupun dideteksi dengan alat-alat medis seperti mengukur kesehatan badan. Berpedoman pada urain tersebut, dapat dipahami bahwa untuk mengukur manusia yang mempunyai mental yang sehat dapat berpatokan kepada hati atau batin yang merasa tenang, aman dan tentram. Sementara pendapat Al-Qussi yang dikutip Askolan Lubis menyebutkan bahwa kesehatan mental ialah keharmonisan yang sempurna antara fungsi-fungsi psikis yang disertai kemampuan untuk menghadapi kegoncangan-kegoncangan batin yang biasa terjadi pada manusia. ${ }^{15}$ Menurut Badan Kesehatan Dunia $(W H O)$ kesehatan mental ialah kemampuan adaptasi manusia dengan diri sendiri dan dengan alam sekitar secara umum, sehingga merasakan senang, bahagia, hidup dengan lapang, berperilaku sosial secara normal, serta mampu menghadapi dan menerima berbagai kenyataan hidup. Berdasarkan pelbagai teori yang disebutkan di atas dapat dipahami bahwa manusia yang sehat secara mental dapat berfungsi secara normal dalam menjalankan kehidupan khususnya saat menyesuaikan diri untuk menghadapai problematika yang akan ditemui sepanjang hidup dengan melalui kemampuan pengelolaan stres.

Berkaitan kesehatan mental yang disebutkan di dalam Al-Quran bahwa Allah mengisahkan Maryam binti Imran mendapatkan bimbingan ketika menghadapi problematika hidup yang berupa hamil tanpa suami. Tetapi kondisi mental mengalami kecemasan dan ketakutan. Ketika manusia mengalami mental yang lemah atau sakit mental, merujuk pada pendapat Thomas. F. Odea bahwa mental yang lemah harus dikuatkan dengan agama. Thomas. F.Odea menjelaskan bahwa ajaran agama mengandung pembinaaan mental yang berupa 1) agama memberikan bimbingan dalam hidup 2) agama menolong dalam menghadapi kesukaran 3) agama dapat menentramkan batin. ${ }^{16}$ Secara tidak langsung peran agama sebagai therapy jiwa yang mengalami kegelisahan dalam menentukan tujuan, putusan dalam menghadap problematika hidup.

Berdasarkan pendapat Thomas. F. Odea, ternyata sesuai dengan fakta yang diabadikan dalam Al-Quran di surat Maryam. Adapun kisahnya dapat diuraikan sebagai berikut ini:

1. Agama memberikan bimbingan dalam hidup

Maryam binti Imran dikisahkan ketika ruh sudah ditiupkan ke dalam rahim oleh malaikat Jibril. Maryam binti Imran takut dan cemas sehingga terbayang sikap cemooh dari Bani Israil. Alhasil Maryam binti Imran berkata "Aduhai, alngkah baiknya aku mati, yakni tidak pernah wujud sama sekali di pentas hidup sebelum ini, yakni sebelum kehamilan ini, agar aku tidak memikul aib dan malu dari satu perbuatan yang sama sekali tidak kukerjakan dan aku menjadi sesuatu yang tidak berarti lagi dilupakan selamalamanya" ${ }_{17}$ M Qurais Shihab pakar tafsir menjelaskan bahwa ketika Maryam binti Imran menghadapi cemooh dari Bani Israil mengalami sakit mental yang berupa rasa menjadi manusia tidak berarti semacam putus asa. Meskipun Maryam binti Imran mengalami sedemikian rupa seperti rasa sedih dan ucapanyanya menggambarkan kecemasan. Allah memberikan bimbingan melalui malaikat Jibrildan diabadikan di surat Maryam ayat 24-25.

\footnotetext{
15 Askolan Lubis, "Peran Agaman Dalam Kesehatan Mental," Jurnal Ihya'ul Al-arabiyah. Vol. 1, No. 2, (2014).

16 Thomas O'dea F. Sosiologi Agama Suatu Pengenalan Awal. Terj. Tim Penerjemah Yasogama (Jakarta: CV Rajawali1985), 9.

${ }^{17}$ M. Quraish Shihab, Tafsir Al-Misbah, 429.
} 
Malaikat Jibril dikisahkan bahwa tidak lama kemudian datang dan berkata "Janganlah, wahai Maryam engkau bersedih hati karena ketersendirian atau ketiadaan makanan dan minuman serta kekhawatiran gunjiingan orang, sesungguhnya Tuhan pemelihara dan pembimbing-mu telah menjadikan anak sungai telaga di bawahmu. Dan goyangkanlah ke kiri dan ke kanan pangkal pohoon kurma itu ke arahmu, niscaya ia yakin pohon itu akan menggugurkan buah kurma yang masak kepadamu”.

Lalupada ayat selanjutnya di ayat 26 dikisahkan malaikat Jibril melanjutkan ucapannya guna memberikan ketenangan kepada Maryam binti Imran bahwa "maka makan dan minum serta bersenang hatilah, dengan kelahiran anakmu. Jika kamu melihat manusia dan dia bertanya keadaanmu, maka katakanlah yakni berilah isyarat yang maknanya sesungguhnya aku telah bernazar berpuasa, yakni menahan diri untuk tidak berbicara demi untuk Tuhan yang Maha Pemurah". Yang dimaksud berpuasa disini adalah agar menghindarkan dari problematika aneka gugatan, sedangkan Allah bermaksud untuk membungkam siapapun yang yang mencurigaimu.

Berdasarkan uraian tersebut dapat dipahami bahwa Allah memberikan dua tahapan ketika membimbingan dalam penyembuhan mental lemah yang dialami Maryam binti Imran berupa peran agama yang memberikan petunjuk sehingga tahap pertama Allah memerintahkan orang-orang terdekat untuk menguatkan dan mendampingi dari proses kehamilan hingga melahirkan. Yang dimaksud orang-orang terdekat bagi Maryam binti Imran ialah malaikat Jibril. Berbeda pandangan apabila yang mengalami problematika tersebut adalah manusia di era milenial, bagi manusia di masa sekarang yang dimaksud orang-orang terdekat ialah ayah, ibu, suami atau keluarga. Merujuk pada pendapat Sarason bahwa dukungan sosial (keluarga) sangat bermanfaat bagi individu lain sebab mendapatkan perhatian emosional, bantuan instrumental, pemberian informasi dan penilaian dari orang lain yang dapat dipercaya ${ }^{18}$ Tahap kedua Allah membimbing melalui petunjuk kepada Maryam binti Imran dalam bentuk berpuasa. Tetapi puasa daam konteks ini adalah berpuasa untuk tidak berbicara, sehingga dapat dimaknai sebagai meminimalisir interaksisi sosial dan berfungsi untuk menghindari cemooh Banilsrailagar tidak terpancing untuk menanggapi berbagai tuduhan yang ditunjukkan kepada diri sendiri, yang dapat memperparah psikis Maryam binti Imran. Berpuasa tidak berbicara dapat diambil hikmahnya, merujuk pada pendapat Nasarudin Umar bahwa puasa berbicara ini sebagai ciri puasa khawash al-khawash. Yang dimaksud khawash al-khawash ialah bukan sekedar menjauhkan diri dari segala bentuk pembicaraan kotor yang dapat memancing emosi dan menjauhkan diri dari pentunjuk Allah yang tersimpan di dalam hati, karena apabila manusia banyak bicara dapat merusak hati. Keinginan untuk berbicara banyak merupakan salah satu kwalitas manusia yang paling merusak. Yang dimaksud merusak ialah mengantarkan kepada pembicaraan yang tidak berguna dan berbohong. Ketika manusia berbohong hati lebih gelisah dan tidak tentram dalam menjalani hidup. Tapi apabila manusia mengerjakan ibadah tersebut dapat membersihkan jiwa dan mengajarkan sifatsifat terpuji yang mampu membuatnya bertahan dalam menghadapi kenyataan hidup. Manusia yang terbiasa melakukan ibadah puasa bicara akan terlatih untuk sabar dalam menghadapi cemooh dan penilaian negatif terhadap dari sendiri dari individul lain di

${ }^{18}$ Sarason I.G. “Assesing Social Support :The Social Support Questionnaire.” Journal of Personality and Social Psychology (1983), 127. 
lingkungan sosial. Dengan demikian dapat dipahami bahwa manusia yang terlalu banyak bicara dan selalu menanggapi komentar individu lain di lingkungan sosial, dapat menyebabkan tekanan, pengalaman emosional yang buruk, pertarungan batin yang menyebabkan menderita penyakit mental, secara tidak langsung berpuasa tidak berbicara di dalam agama dapat berfungsi sebagai media psikoterapi yang mujarab.

2. Agama Menolong dalam Menghadapi Kesukaran

Menurut Freud bahwa agama merupakan tempat pelarian dari kelemahan manusia. Teori tersebut diperkuat dengan pendapat Hardjana bahwa agama dapat memberikan penjelasan terhadap berbagai fenomena yang tidak dapat dijelaskan oleh pikiran manusia karena atas keterbatan dan kelemahan yang tidak mampu mencapai ranah Allah untuk menyelesaikan problematika hidup manusia. Berdasarkan penjelasan di atas dapat dipahami bahwa agama merupakan suatu wahana untuk meningkatkan kesadaran dari yang normal menujukesadaran supra-normal/transendental. Yang dimaksud kesadaran normal menuju kesadaran supra-normal ialah peristiwa yang tidak mungkin diterima oleh pikiran, akan tetapi dapat terjadi begitu saja sesuai atas kehendak Allah untuk membantu kesukaran yang dihadapi manusia.Peristiwa kesadaran normal menuju ke kesadaran supranormal/transendental di dalam Alquran banyak dikisahkan.

Salah satu kisah yang diabadikan di dalam Alquran ialah kesadaran yang dialami oleh Maryam binti Imran. Pada intinya Alquran mengisahkan bahwa kesukaran yang dialami Maryam binti Imran berupa kehamilan tanpa suami dan menghadapi sikap tuduhan zina yang dilontarkan dari Bani Israil. Sehingga Maryam binti Imran sedih dan mengalami kecemasan untuk menghadapi problematika tersebut. Kondisi sedih dan kecemasan yang dialami Maryam binti Imran menandakan bahwa manusia itu sangat lemah menghadapi berbagai macam cobaan hidup. Keadaan yang dialami Maryam binti Imran sesuai dengan pendapat Subandi bahwa bahwa manusia itu sangat lemah menghadapi berbagai macam cobaan dan problematika kehidupan. Sehingga manusia dituntut untuk segera mencari solusi penyelesaian dari persoalan kehidupan sosial tersebut ${ }^{19}$.

Maryam binti Imran mencari solusi penyelesain dengan mendekatkan diri kepada Allah melalui agama. Alquran mengisahkan bahwa Maryam binti Imran berusaha selalu mengingat kepada Allah dengan cara berdzikir di tempat yang sepi jauh dari lingkungan sosial. Maryam binti Imran bersikap demikian memiliki tujuan bahwa Maryam binti Imran ingin mengangkat jiwanya, ingin mempertahankan kehidupan di dunia dan di akhirat. Dengan demikian berdasarkan pendapat Syaiful Hamali bahwa manusia mempunyai kebutuhan yang fundamental akan nilai-nilai metafisis dan norma keagamaan untuk mengatasi konflik, ketenangan, kegelisahan yang membawa kepada frustasi ${ }^{20}$. Secara psikologi keberadaan agama merupakan tanggapan manusia terhadap Allah sebagai pencipta alam semesta sekaligus maha segalanya. Dengan agama manusia menyadari keberadaannya di dunia sebagai makhluk yang memiliki keterbatasan. Sementara Freud beranggapan bahwa manusia beragama hanya untuk mencari figur yang lebih kuat, lebih perkasa dan lebih kuasa dengan tujuan mendapatkan perlindungan. Berdasarkan uraian dan teori tersebut dapat dipahami bahwa agana menawarkan penjelasan atas problemati hidup manusia.

\footnotetext{
${ }^{19}$ Subandi,Psikologi Agama Dan Kesehatan Mental. (Yogyakarta: Pustaka Pelajar, 2019), 34.

${ }^{20}$ Syaiful Hamali, "Terapi Agama Terhadap Promblematika Psikis Manusia".Jurnal Al-Adyan IX Nomor. 2
} 
al-Quran mengisahkan penyelesaian/penjelasan atas problematika hidup yang dialami Maryam binti Imran berupa perintah untuk menghadapi Bani Israilyang memfitnah Maryam binti Imran sebagai pezinah dengan menggendong bayinya untuk dihadapkan kepada Bani Israil. Dan itu dilakukan tanpa merasa malu, bahkan dengan percaya diri. Atas kebesaran sifat sabar dan pasrah kepada kepercayaan ajaran-ajaran agama. Allah memberikan pertolongan dalam bentuk mukjizat. Mukjizat tersebut berupa bayi yang masih dalam gendonggan mampu berbicara untuk menjelaskankehamilan yang dialamiMaryam binti Imran. Semenjak kelahiran Nabi Isa diberi kuasa dapat berbicara selayaknya orang dewasa $^{21}$. Kemampuan tersebut diberikan untuk berupaya keras menyelamatkan status sosial Maryam binti Imran dari tuduhan Bani Israil sebagai anak hasil perzinaan.Tuduhan perzinaan yang dialami Maryam binti Imran sebagai pertanda adanya krisis identitas sosial yang menyangkut harga diri Maryam binti Imran dan Isa bin Maryam. Berdasarkan uraian di atas dapat dipahami bahwa mukjizat tersebut tercipta atas sikap keyakinan Maryam binti Imran terhadap agama, sehingga pertolongan dari Allah datang dan sebagai pertanda solusi untuk menyelesaikan problematika hidup yang dialami Maryam binti Imran. Solusi tersebut datang dengan cara putera Maryam binti Imran menyanggah semua tuduhan dari bani Israil. Bahkan menegaskan jati diri nabi Isa sebagai hamba Allah sekaligus utusan Allah dan pembawa kitab Injil.

\section{Peran Agama dalam Kesehatan Mental}

Dengan demikian teori dan penjelasan tersebut dapat dipahami bahwa Allah menyimpan pesan tersirat yakni kesehatan mental dapat diperoleh melalui Agama yang diletakkan bersama keyakinan ibadah. Yakni berusaha mendekatkan diri kepada sang pencipta melalui sikap tunduk, bertaqwa, beribadah dengan baik agar dapat memperoleh ketenangan, dan penyelesain atas problematika hidup yang dialami, sehingga hidup lebih bahagia di dunia dan akhirat.

Ketenangan batin adalah sumber kebahagian. Manusia tidak akan mengalami perasaan bahagia apabila batin tidak tenang dan gelisah. Sedangkan yang dimaksud batin ialah jiwa, untuk sampai pada ketenangan jiwa maka perlu mendekatkan diri kepada agama. Dalam artian kebutuhan fisik dan batin harus sama-sama seimbang. Untuk itu terkait dengan upaya memenuhi kebutuhan batin supaya menciptakan ketenangan jiwa, Al-Ghazali berpendapat bahwa manusia totalitas jiwa-raga, sebagai makhluk metafisis yang dikonkritkan oleh badan jasmani. Aspek jasmani berperan untuk mendorong perkembangan dan ketenangan jiwa. Yang dimaksud ketenangan batin dalam pandangan Al-Ghazali bahwa kesempurnaan jiwa bukan sebuah fenomena yang stabil dan permanen, akan tetapi sebuah pencapaian prestasi psikologis yang diisitilahkan dengan akhwal setelah mencapai proses pendidikan dan pelatihan tertentu. Dalam pandangan Al-Ghazali ketenangan batin dapat ditempuh dengan memperbanyak dzikir pada Tuhan dan sementara waktu menjauhkan diri dari lingkungan sosial22. Berdasarkan penjelasan tersebut dapat dipahami bahwa melalui dzikir kebutuhan yang bersifat psikis dapat terpenuhi sehingga memberikan ketenangan dan kebahagian, selain

\footnotetext{
${ }^{21}$ M. Quraish Shihab, TafsirAl-Misbah, 441.

22 Abdul Syakur, "Metode Ketenangan Jiwa Suatu Perbandingan Antara Al-Ghazali Dan Sigmund Freud," Jurnal Islamica Vol. 1 N (2007).
} 
itu memperbanyak dzikir dapat membimbing jiwa manusia untuk memberikan motivasi dalam menghadapi cobaan hidup sehingga tidak melupakan Allah yang Maha Kuasa.

Salah satu peran penting dari agama adalah memberikan rasa ketenangan dalam menghadai cobaan hidup dan peran tersebut diimplementasikan dalam ajaran Islam dalam bentuk berdzikir. Menurut Moh Sholeh bahwa Islam menganjurkan agar manusia untuk melaksanakan dzikir kepada Allah. Perintah tersebut sangat dianjurkan karena berdzikir hati akan menjadi terasa lebih tenang dan damai. Artinya apabila manusia melakukan dzikir memiliki makna bahwa permasalahan dunia diserahkan kepada Allah yang Maha kuasa ${ }^{23}$. Berdasarkan teori dan penjelasan di atas dapat dipahami bahwa segala bentuk ibadah (ajaran agama) yang dikerjakan terumata dzikir dapat mempengaruhi mental agar tetap kuat dan sehat. Yang dimaksud berdzikir ialah cara manusia mendekatkan diri kepada Allah dengan tujuan untuk menciptakan ketenangan dan kedamaian jiwa dalam menghadapi segala problematika hidup di dunia. Selain itu berdzikir dapat memberikan kontribusi yang sangat besar terhadap badan, hati dan jiwa agar tetap sehat secara psikologi. Manusia yang terbiasa berdzikir tidak akan melakukan perbuatan tercela dan menyakitkan hati orang lain.

Berdzikir dapat dimaknai cara untuk menyehatkan batin manusia. Menurut pendapat AlGhazali manusia terdiri dari dua dimensi yakni material/fisik dan spiritual/batin, sehingga kedua dimensi tersebut perlu ditumbuh kembangkan agar kesehatan mental dapat tercapai secara sempurna ${ }^{24}$ Selain itu, Muhammad Audah dan Kamal Ibrahim menanggapi pendapat Al-Ghazali bahwa pentingnya dimensi spiritual dalam memandang kesehatan mental bagi manusia harus memiliki indikator yang mencakup dimensi-dimensi kehidupan antara lain ${ }^{25}$ :

1. Dimensi Spiritual, terdiri dari keimanan kepada Allah, melakukan ibadah, menerima ketentuan dan takdir Allah, berusaha mendekatkan diri kepada Allah dengan cara selalu berdzikir kepada Allah.

2. Dimensi Psikologi, terdiri dari kejujuran, terbebas dari rasa dengki iri, merasa percaya diri, mampu menanggung kegagalan dan rasa gelisah, menjauhi hal-hal yang menyakiti jiwa, memiliki keseimbangan emosional, lapang dada, mudah menerima kenyataan hidup, mampu mengendalikan, mengekang hawa nafsu dan tidak terlalu berambisi.

3. Dimensi Sosial, terdiri dari mencintai kedua orang tua, rekan dan anak, membantu orang yang membutuhkan, bersikap amanah, berani mengatakan yang benar, bertangungjawab dan menjauhi hal-hal yang dapat menyakiti orang lain seperti berbohong, memanipulasi, mencuri, berzina, membunuh, memberikan saksi palsu, memakan harta anak yatim, memfitnah, khianat dan suka berbuat dzalim.

4. Dimensi Biologis terdiri dari sehat dari berbagai penyakit, tidak cacat fisik, memperhatikan kesehatan, dan tidak membebani fisik sesuia dengan kemampuannya.

Berdasarkan indikator di atas dapat dipahami dan digambarkan bahwa Maryam binti Imran yang dikisahkan di dalam Alquran memiliki psikis yang benar-benar sehat. Sebab manusia yang sehat mental ialah yang beriman dan bertaqwa kepada Tuhan yang Maha Esa dan berusaha secara sadar untuk berlapang dada dalam menerima segala ketentuan dan takdir dari Allah. Kisah tersebut diabadikan oleh Allah di Surat Maryamayat 27-28 yang berbunyi ${ }^{26}$ :

\footnotetext{
${ }^{23}$ Moh Sholeh,Tahajud Manfaat Praktis Ditinjau Dari Ilmu Kedokteran Terapi Religius (Yogyakarta: Pustaka Pelajar 2005), 27.

${ }^{24}$ Abdul Syakur, "Metode Ketenangan Jiwa Suatu Perbandingan Antara Al-Ghazali Dan Sigmund Freud."Jurnal Islamica, Vol. $1 \mathrm{~N}$ (2007)

${ }^{25}$ Ikhwan Fuad, "Menjaga Kesehatan Mental Perspektif Alquran Dan Hadits," Jurnal An-Nafs, Kajian dan Penelitian Psikologi, Vol. 1 N (2016).

${ }^{26}$ M. Qurais Shihab, Tafsir Al-Misbah, 434.
} 
"Maka dia membawanya kepada kaumnya dengan menggendongnya. Mereka berkata: wahai Maryam, sesungguhnya engkau telah melakukan sesuatu yang mungkar. Wahai saudara perempuan Harun, ayahmu sekali-kali bukanlah seorang yang buruk dan ibumu sekali-kali bukanlah seorang pezina."

Ayat di atas menunjukkan bahwa Maryam binti Imran datang dengan sengaja sambil mengendong anaknya untuk menghadap kaumnya. Dan itu dilakukannya tanpa merasa malu, bahkan dengan penuh percaya diri. Berdasarkan inti dari ayat tersebut dapat dipahami bahwa perilaku Maryam binti Imran yang percaya diri dalam menghadapi kaumnya memiliki indikator psikis yang sehat. Pernyataan tersebut perpedoman kepada pendapat Muhammad Audah dan Kamal Ibrahim bahwa manusia dikatakan memiliki psikis yang sehat, salah satunya dapat dilihat pada dimensi psikologi yang dapat ditunjukkan dengan sikap merasa percaya diri.

Rasa percaya diri yang dimiliki Maryam binti Imran didapat melalui kegiatan uzlah (menyepi) dari lingkungan sosial sehingga Maryam binti Imran dapat lebih fokus untuk melakukan berdzikir. Tujuannya tidak lain hanya untuk mengingat kepada Allah dan mentauhidkan Allah. Sebab iman yang kuat tertanam di dalam hati dapat menciptakan rasa lapang dada, ridho dan bahagia dalam diri manusia. Hal ini sebagaimana tercatat dan terabadikan di dalam Alquran bahwa Maryam binti Imran selama merasa kecemasan dan ketakutan yang diiringi dengan usaha susah payah untuk tetap mengingat Allah. Akhirnya pertolong datang dalam bentuk malaikat Jibril yangbertugas untuk menenangkan psikisnya.

Peristiwa tersebut dapat dilihat pada Surat Maryam ayat 26 yang berbunyi sebagai berikut:

"Maka makan dan minum serta bersenang hatilah. Jika engkau melihat seseorang manusia, maka katakanlah "sesungguhnya aku telah bernazar berpuasa untuk Tuhan Yang Maha Pemurah, maka aku tidak akan berbicara dengan seseorang manusia pun pada hari ini."

Yang dimaksud bernazar untuk berpuasa tidak akan berbicara merupakan salah satu cara ibadah untuk mengheningkan cipta. Mengheningkan cipta dapat dimaknai sebagai usaha untuk mencari ketenangan batin yang dilakukan dalam bentuk Uzlahagar terhindar dari gangguan cemooh dan celaan Bani Israil. Setelah Maryam binti Imran mendengar kalimatkalimat seperti yang tercantum dan terbaca pada ayat-ayat sebelumnya ini. Maryam binti Imran merasa hati menjadi tenang, tegar dan kesedihan akan sirna, deengan datanganya pertolongan Allah. ${ }^{27}$ Dengan demikian dari penjelasan dan teori di atas bahwa terapi agama dapat dipahami sebagai jenis perawatan dan penyembuhan penyakit dengan mengunakan metode psikologi yang dipadukan dengan ajaran agama terhadap permasalahan-permasalahan yang bersumber dari kehidupan emosional untuk dikembalikan kepada kesehatan dan keseimbangan psikis manusia.

\section{Penutup}

Berdasarkan teori dan uraian tersebut dapat dipahami bahwa manusia akan merasa dalam perlindungan dan penjagaan Allah serta mendapatkan bimbingan hidup ketika manusia berusaha untuk mendekatkan diri kepada Allah sehingga membuatnya menjadi tenang dan

\footnotetext{
${ }^{27}$ Mahmud Yunus. Perkembangan Jiwa Agama Serta Peranan Psikologi Agama Dalam Kesehatan Mental (Bandar Lampung: Gunung Pesagi, t.t), 107.
} 
tentram. Sebagaimana firman Allah yang tercatat di Surat Ar-Ra'ad ayat 28 sebagai berikut ini: "Orang-orang yang beriman dan hati mereka menjadi tenteram dengan mengingat Allah. Ingatlah hanya dengan mengingat Allah hati menjadi tentram." Pada intinya usaha dalam penguatan dimensi spiritual dapat dilakukan dengan tahapan ibadah untuk menanamkan iman dan tauhid seperti melaksanakan ajaran-ajaran agama. Jika tahapan ini dapat dilaksanakan dengan baik maka kepribadian yang kuat akan terbentuk. Pada akhirnya akan mengantarkan manusia kepada kebahagian dan kesehatan mental bahkan mampu mengembangkan potensi diri secara sempurna. Sementara Mahmud Yusuf mengutip pendapat Norma Vincent Peale bahwa agama yang dapat memberikan rasa keimanan dan rasa keyakinan kepada manusia dalam bentuk sikap pasrah dan memohon pertolongan kepada Allah dari segala hal yang tidak menyenangkan dan dari problematika hidup yang dihadapi.

\section{Daftar Rujukan}

Drajat, Zakiah. Kesehatan Mental. Jakarta: Gunung Agung, 1995.

—. Pendidikan Agama Dalam Membina Mental. Jakarta: N.V Bulan Bintang, 1982.

- Peran Agama Dan Kesehatan Mental. Jakarta: Masagung, 1990.

Fuad, Ikhwan. "Menjaga Kesehatan Mental Perspektif Alquran Dan Hadits."Jurnal An-Nafs, Kajian dan Penelitian Psikologi, Volume 1, 2016.

Ghazali, Bahri. Kesehatan Mental II. Bandar Lampung: Harko Indo, 2008.

Hamali, Syaiful. "Terapi Agama Terhadap Promblematika Psikis Manusia." Jurnal Al-Adyan IX Nomor 2, 2014.

Hasan, Zainol. "Nilai-Nilai Pendidikan Islam Pada Kisah Nabi Ibrahim."Jurnal Nuansa Vol. $14,2017$.

Lubis, Askolan. "Peran Agaman Dalam Kesehatan Mental.” Jurnal Ihya'ul Al-arabiyah Vol. $1 \mathrm{~N}, 2014$.

Mulyadi. "Agama Dan Pengaruhnya Dalam Kehidupan.” Jurnal Tarbiyah Al-Awlad VI Edisi $0,2016$.

Najati. Alquran Dan Ilmu Jiwa. Bandung: Pustaka, 1985.

Nasution, A Faruq. Thibburruhany Atau Faith-Heeling Psikology (Iman Dalam Kesehatan Jiwa Dan Badan), Jakarta: Publik Komunikasi Ilmiah Ulum Eldine, 1976.

O’dea, Thomas. F. Sosiologi Agama Suatu Pengenalan Awal. Terj. Tim Penerjemah Yasogama. Jakarta: CV Rajawali, 1985.

Rosyad, Rifqi. "Pengaruh Agama Terhadap Kesehatan Mental." Jurnal Shifa Al-Qulub Vol. I N, 2016.

Sarason, I.G. “Assesing Social Support:The Social Support Questionnaire.” Journal of Personality and Social Psychology, 1983.

Shihab, M Quraish. Tafsir Al-Misbah, Pesan, Kesan Dan Keserasian Alquran, Volume 7. Jakarta: Lentera Hati, 2002.

Sholeh, Moh. Tahajud Manfaat Praktis Ditinjau Dari Ilmu Kedokteran Terapi Religius. Yogyakarta: Pustaka Pelajar, 2005.

Subandi. Psikologi Agama Dan Kesehatan Mental. Yogyakarta: Pustaka Pelajar, 2019.

Syakur, Abdul. "Metode Ketenangan Jiwa Suatu Perbandingan Antara Al-Ghazali Dan Sigmund Freud." Jurnal Islamica Vol. 1, N, 2007.

Yusuf, Mahmud. Perkembangan Jiwa Agama Serta Peranan Psikologi Agama Dalam Kesehatan Mental. Bandar Lampung: Gunung Pesagi, n.d.

Zed, Mestika. Metode Penelitian Kepustakaan. Jakarta: Yayasan Obor Indonesia, 2003. 